DOI 10.31168/2618-8597.2021.16.05

\title{
FOUND IN TRANSLATION: \\ ENCODING THE SOURCE OF FEAR BY CASES AND PREPOSITIONS IN THE BALKAN LANGUAGES
}

\section{Ekaterina Tarpomanova}

Saint Kliment Ohridski University of Sofia (Bulgaria) tochitsaaa@gmail.com

Bilyana Mihaylova

Saint Kliment Ohridski University of Sofia (Bulgaria) bilydim@gmail.com

\section{FEAR AND ITS REPRESENTATION IN LANGUAGE}

In all psychological classifications, fear is presented as one of basic and most universal human emotions. It causes standard reactions, known as fightor-flight response, which, to all appearances, have similar lexicalizations in languages. The semantic development of words denoting fear is often transparent: the words meaning 'fear, fright' in human languages commonly originate from lexemes with primary semantics connected to the physical actions or expressions of this emotion as 'go away, run', 'tremble, shake; be cold, chilly shiver', 'freeze, be stiff, be paralysed; catch, grasp', 'be struck' (Buck 1949: 1153). The human behaviour as a response of fear may be encoded in grammar, too. In a previous work we analyzed the verb diathesis in fear constructions, which, in our view, represents the fear as an inner experience in the languages of the Balkan Sprachbund (Tarpomanova, Mihaylova, Krastev 2019). In this paper we will focus on the way the universal reaction of distancing from the source of fear may be represented by grammatical means. In many languages, the fear constructions are a metaphorization of the avoidance response to fear. Our aim is to show how the psychological reaction and the resulting behaviour are translated by means of grammatical features and furthermore the correspondences of those metaphorical translations between the Balkan languages that are due to the processes of interference in the development towards analytism of their noun systems. 


\section{TwO STRATEGIES TO ENCODE THE STIMULUS IN FEAR CONSTRUCTIONS}

The argument structure of predicates denoting the emotion of fear involves two participants: the experiencer and the stimulus. The experiencer of the psychological state can appear as either the subject (ES: Mark fears Mary) or the direct object (EO: Mary frightens Mark). Verbs like fear describe a habitual attitude towards some entity whereas verbs like frighten describe an externally caused emotional episode (Hartshorne et al. 2016: 268). Here we will explore the rection of the verbs from the fear-type where the experiencer is mapped as subject.

The patterns by which semantic structures of fear verbs are conceptualized syntactically in human languages are different. Two main strategies may be outlined in the syntactic expression of the stimuli of fear when the experiencer appears as subject: (i) The stimulus is encoded as direct object in opposition to the higher thematic role of the experiencer (Grimshaw 1990: 16, Temme 2018: 13) as a consequence of a cognitive process where the experiencer pre-existed the stimulus. (ii) The stimulus is introduced by oblique cases (genitive/ablative and more rarely by instrumental) or prepositions expressing distancing behaviour (Lakey 2016: 42) the fleeing being the most common reaction to the fear.

The first strategy may be seen in many languages of the world, see the data extracted in Valency Patterns Leipzig Online Database (ValPaL). Languages as Arabic, Japanese, Bora encode the fear stimuli in Accusative. Concerning the Balkan areal in Antiquity this was the common strategy in Ancient Greek and Latin.

The second strategy is attested in many Indo-European languages, including all the Slavic languages, Old Persian, Armenian, but also in Evenki (a Tungusic language) and Ket (a Dené-Yeniseian language).

\section{TRANSLATING STIMULUS IN ANCIENT LANGUAGES ON THE BALKANS}

2.1. The main Latin ES verbs for fear, regardless of their origin, are active and transitive, i.e. the fear stimulus is expressed in accusative: time $\bar{o}$,

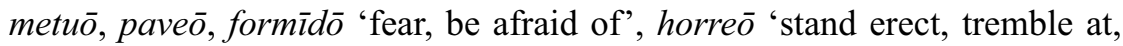
be afraid of', tremō 'tremble at, be afraid of', trepid̄ 'tremble at, be afraid of'. In Latin only the verb vereor 'feel awe of, reverence, revere, respect; fear, be afraid of' is deponent, i.e. inactive. 
2.2. In Ancient Greek we find both strategies of expression of the stimulus. However, it is most often encoded as direct object.

2.2.1. Stimulus encoded as direct object

$\delta \varepsilon i \delta \omega$ (old perfect * $\delta \varepsilon-\delta \digamma \mathrm{Fol} \alpha$ ) 'fear; be alarmed, be anxious';

$\tau \rho \varepsilon ́ \mu \omega$ 'tremble, quake, quiver; tremble with fear; tremble at, fear';

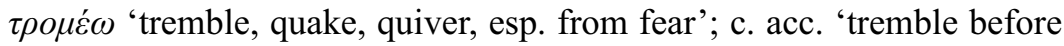
or at a person, stand in awe of';

$\tau \rho \varepsilon \dot{c} \omega$ 'turn to flee, flee in terror, be afraid, fear.'

2.2.2. Stimulus introduced by the preposition $i \pi \grave{o}$ followed by genitive

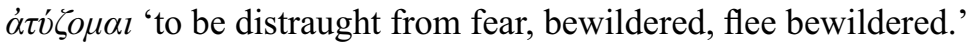

\subsubsection{State of transition}

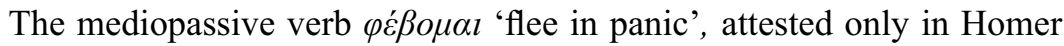
and his imitators, the intransitive middle iterative $\varphi \circ \beta$ '́ $о \mu \alpha l$ 'to be put to flight (Hom), terrify, alarm (Hom + )' and the transitive active causative $\varphi \circ \beta \varepsilon \dot{c} \omega$ 'put to flight (Hom), to be seized with fear, be affrighted (Hom+)', which is a back-formation from $\varphi \circ \beta \varepsilon \varepsilon^{\circ} \mu \alpha l$ according to Jasanoff (2003: 134), are related to PSl. *bĕgati $<\mathrm{IE}{ }^{*} b^{h} e g^{w_{-}}$'run, flee'. The inactive verbs $\varphi \dot{\varepsilon} \beta \beta_{\mu \alpha l}$ and

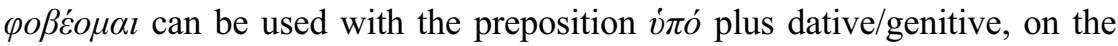
one hand, or as transitive with accusative, on the other.

The semantic transformation from movement (flight) to emotion (fear) has been accompanied by changes in the predicate structure of the mediopassive, which affected the realization of the internal argument. In Homer $\varphi o-$ $\beta \varepsilon$ co $_{\alpha} \mathrm{l}$ is used with the genitive/dative, rarely with the accusative, or with the preposition $i \pi \dot{o}$, while in Thucydides (5th century BC) the semantic change is already present: the active transitive verb means 'terrify, alarm', and the inactive one means 'fear' and is used with the accusative (see also Kitis 2009: 436 sqq.)

2.3. In Old Church Slavonic the stimulus of fear type verbs is expressed with ablative preposition or genitive case. It is well known that the ablative has been lost and its functions have been subsumed under the genitive marker.

Б Вё NE БOLK CA (CP)

'I am not afraid of evil spirits.'

NE OYBOIT CFA ZZRA BKO TZI CO MNOF ECI (CP)

'I am not afraid of evil if you are with me.'

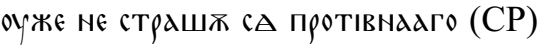

'I am no longer afraid of the enemy.' 
2.4. In the ancient languages in the Balkan area, the predominance of the first strategy of marking the stimulus in fear constructions is obvious: the stimulus is encoded as a direct object in all Latin and in most Ancient Greek verbs, including $\delta \varepsilon i \delta \omega$, the basic verb expressing fear in Ancient Greek. In Old Church Slavonic, the second strategy which encodes distancing behavior is used exclusively.

\section{TRANSLATING FEAR STIMULUS IN THE MODERN BALKAN LANGUAGES}

3.1. Fear stimulus translated by cases

As it is well-known, one of the main common features in the analytical development of the noun system of the Balkan languages is the fusion of genitive and dative: in Bulgarian and Romanian they are formally expressed by the dative inflection, while in Greek it is the genitive that bears the functions of the dative (cf. Асенова 2002: 81). In Albanian the two cases do not differ formally, and additionally the ablative has a different inflection for the indefinite plural (-sh), which has emerged from an old Locative (Demiraj 1973: 64).

3.1.1. After the process of case fusion has been accomplished, the dative assumed the functions of the genitive (and the ablative) covering also the meaning of distancing in the case of verbs expressing fear. This outcome is particularly noticeable in Albanian, where the majority of the verbs for fear are used with the Dative. In Romanian the dative may be found in several periphrastic constructions.

Alb. Nuk i frikem vdekjes. 'I don't fear death.'; Nuk u tutet vështirësive. 'He is not afraid of the difficulties.'; I trembej atij. 'He was afraid of him.' (FShS)

Rom. a duce frica cuiva 'be afraid of somebody', lit. 'bring fear to somebody'; a lua frica cuiva 'be afraid of somebody', lit. 'take the fear of somebody' (РБФР 403); Are frica lui Dumnezeu. (collocation) 'He has fear of God.'

As in Bulgarian, the development towards analytical noun system resulted in complete loss of the cases, the correspondence of the dative pattern is a prepositional phrase headed by на, which may be replaced by a dative pronominal clitic.

Bulg. Не му се плаша. (МДАБЯ 186) 'I am not afraid of him'; Никога не съм правила козунак, имам му страх от едно време. (svatbata.bg) 'I have never made Easter cake, I have been afraid of it ever since.' 
However, the dative pattern of fear constructions in Bulgarian is rather rare and limited to dialectal and colloquial use.

3.1.2. The accusative remains a sustainable strategy mainly for active verbs and, additionally, for the Greek deponent verb $\varphi \circ \beta \alpha \dot{\alpha} \mu \alpha l$.

Alb. S’i druajmë armiqtë. (FShS) 'We are not afraid of the enemies.'

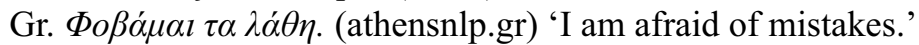

In Old and Middle Romanian the verb a teme appears as active (inherited from Latin) or as reflexive (possibly a Slavic influence according to Pușcariu 1940: 277). The number of the reflexives increases in the Middle Romanian period (Pană Dindelegan 2016: 206-207). The verb can be used with the dative, with a prepositional phrase, and with the accusative (ib. 76). The raise of the Dative constructions are explained with Slavic influence (ib. 88). These variants were eliminated from standard Romanian (ib. 86) but are still maintained in XIX-century literature:

$\mathrm{Tu}$, ce nu temi furtuna și durerea... (Mihai Eminescu, Odin şi poetul) 'You, who don't fear fortune and suffering...'

$N$-ai frică de trăsnet? Teme pe zei? (George Coșbuc (trad.), Virgiliu, Eneida) 'Aren't you afraid of thunderbolts? Are you afraid of the gods?'

Interestingly enough, the Albanian expression kam frikë 'be afraid', lit. 'have fear', may also adhere a stimulus in the accusative, although the position of the direct object is already taken by the noun frikë, unlike the corresponding expressions in the other Balkan languages.

Nuk i urrej njerëzit, i kam frikë. (facebook) 'I don't hate people, I am afraid of them.'

A possible explanation could be the semantic bleaching of the noun and the higher degree of bondedness between the two elements of the construction, or in other words the grammaticalization of the expression, which allows the stimulus to be marked with the accusative.

\subsection{From cases to prepositions}

At a very early stage of the development of the Indo-European languages, the prepositions appeared to support the cases in order to express the syntactic relations in a more clear or detailed way. They gradually enlarged their functions and became the main means for the expression of syntactic relations, thus contributing for the weakening of the cases or fully replacing them in some languages (Meillet, Vendryes 1924: 481; Demiraj 1973: 63).

It has been claimed that in the Balkan languages many prepositions have been grammaticalized to express certain abstract and general relations 
(cf. Асенова 2002: 97). One of the grammaticalized prepositions of the Balkan linguistic area is Bulg. om, Gr. $\alpha \pi$, Rom. de (de la, din), Alb. nga, prej, which among its other functions is the main means to introduce the stimulus in fear constructions. The primary and the earlier meaning of those prepositions, known since Ancient Greek, Latin and Old Church Slavonic, is that of moving away. From that particular meaning further related and more general meanings have been developed, such as possessive, partitive, origin, starting point in time or space, and some more recent senses, not directly connected to the initial one, like transgression, quantity, time scope, way of action (Асенова 1972: 235-236). The same prepositions have been grammaticalized to denote the agent in passive constructions and the so-called standard NP (Stassen 2013) in comparative constructions.

In the modern Balkan languages, the preposition Bulg. om, Gr. $\alpha \pi$, Rom. de, Alb. nga, prej is one of the main means to denote the stimulus in fear constructions.

Bulg. Тя се страхуваме от него. (alle.bg) 'She was afraid of him.'; Плаша се от тъмното. (ask.fm) 'I'm afraid of the dark.'

Alb. Nuk frikësohem nga lartesia. (FShS) 'I am not afraid of height.'; Tutet prej tij. (FShS) 'He is afraid of him.' Tutet nga hija e vet. (FShS) 'He is afraid of his own shadow.' Kam frikë prej danajve edhe kur sjellin dhurata. (Virgjili, Eneida) 'I fear the Danaans, even when bringing gifts.'

Rom. Nu mă tem de moarte, dimpotrivă. (George Topîrceanu, Balade vesele şi triste, Infernul) 'I am not afraid of death, on the contrary.'; Se sperie şi de umbra lui. (collocation) 'He is afraid even of his shadow.'

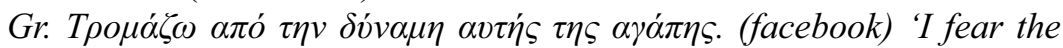

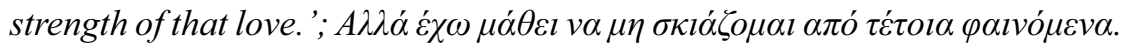
(tanea.gr) 'But I learned not to be afraid of such events.'

The preposition $\alpha \pi \delta$ in Greek may even occur with the verb $\varphi о \beta \alpha \dot{\alpha} \mu \alpha$, which as a rule requires a direct object marked by the accusative.

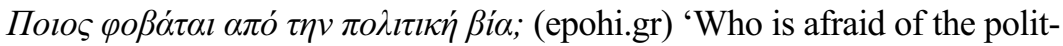
ical life?'; fov'ame ap'o to sk"ilo su. (МДАБЯ 186) 'I am afraid of your dog.'

There are two reasons for the establishment of the prepositions as a main strategy to express the stimulus in fear constructions: a semantic and a syntactic one. Considering the semantic side, the prototypical meaning of the prepositions fully corresponds to the avoidance response to the fear, i.e. moving away from the stimulus. On the other hand, the fact that the prepositions under consideration occur mostly with inactive verbs expressing fear could also be connected with their grammaticalization in passive constructions. 


\section{Conclusions}

In the Balkan area, a diachronic tendency is well observed. The ancient languages (Latin and Greek) show a preference for the first strategy in marking the stimulus of fear constructions, i.e. the stimulus is encoded as direct object, while in the modern Balkan languages clearly predominates the second strategy which translates by grammatical means the avoiding behaviour as physical reaction to the fear. The course of this process is clearly seen in the development of Gk. $\varphi о \beta \alpha ́ \mu \alpha \iota ~ u$ Rom. a teme.

The development towards analytism of the noun systems of the Balkan languages resulted in the domination of the prepositional expression of the stimulus in fear constructions. In Greek, Bulgarian and Romanian the prepositional expression is the most frequent pattern, which in Greek may be found even with the traditionally deponent verb $\varphi о \beta \alpha \mu \alpha l$ instead of the accusative. In Albanian, the case (dative) and the prepositional (nga, prej) pattern compete, both occurring in fear constructions as they code the metaphor of distancing.

Acknowledgement: The research is supported by the Scientific Research Fund of the Ministry of Education and Science of Bulgaria, project The Balkan languages as emanation of the ethno-cultural community of the Balkans (Verb typology), contract DN 20/9/11.12.2017.

\section{REFERENCES}

Buck $1949-$ Buck C. D. A Dictionary of selected synonyms in the principal IndoEuropean languages. Chicago: The University of Chicago Press, 1949.

Demiraj 1973 - Demiraj Sh. Morfologjia historike e gjuhës shqipe. Pjesa I. Tirana: Drejtoria Qendrore e Poligrafisë, 1973.

FShS - Fjalor i shqipes së sotme. Tirana: Botimet Toena, 2002.

Grimshaw 1990 - Grimshaw J. Argument structure. Cambridge, MA: MIT Press, 1990. (Linguistic inquiry monographs.)

Hartshorne et al. 2016. - Hartshorne J. K., O’Donnell T. J., Sudo Y., Uruwashi M., Lee M., Snedeker J. Psych verbs, the linking problem, and the acquisition of language // Cognition 157, 2016. P. 268-288.

Kitis 2009 - Kitis E. From motion to emotion to interpersonal function: The case of fear predicates // Pishwa H. (ed.). Language and social cognition: Expression of the social mind. Berlin: Mouton de Gruyter, 2009. P. 433-454. 
Lakey 2016 - Lakey H. A. The grammar of fear: Morphosyntactic metaphor in fear constructions. (PhD Dissertation), Available online at https://www.academia.edu/ 32864441/THE_GRAMMAR_OF_FEAR_MORPHOSYNTACTIC_METAPHOR_ IN_FEAR_CONSTRUCTIONS, Accessed on 2021-02-23.

Stassen 2013 - Stassen L. Comparative constructions // Dryer M. S., Haspelmath M. (eds.). The world atlas of language structures online. Leipzig: Max Planck Institute for Evolutionary Anthropology, 2013. (Available online at: http://wals.info/ chapter/121, Accessed on 2021-02-21.)

Meillet \& Vendryes 1924 - Meillet A., Vendryes $J$. Traité de grammaire comparée des langues classiques. Paris: Champion, 1924.

Pană Dindelegan 2016 - Pană Dindelegan G. (ed.). The syntax of Old Romanian. Oxford: Oxford University Press, 2016.

Pușcariu 1940 - Pușcari, S. Limba română. Vol I. Privire generală. București: Fundația pentru Literatură și Artă „Regele Carol II”, 1940.

Tarpomanova, Mihaylova, Krastev 2019 - Tarpomanova E., Mihaylova B., Krastev $N$. Emotions in grammar: fear in the Balkan languages // Балканский тезаурус: коммуникация в сложно-культурных обществах на Балканах / Отв. ред. И. А. Седакова, ред. М. М. Макарцев, Т. В. Цивьян. М.: Институт славяноведения РАН, 2019. Р. 68-74. (Балканские чтения. 15.)

Temme 2018 - Temme A. The peculiar nature of psych verbs and experiencer object structures. (PhD Dissertations, Humboldt University). (Available online at https://edoc.hu-berlin.de/bitstream/handle/18452/20689/dissertation_temme_ anne.pdf? sequence=3, Accessed on 2021-02-21.)

ValPaL - Valency patterns Leipzig online database. (Available online at: http:// valpal.info/, Accessed on 2021-02-23.)

Асенова 1972 - Асенова П. Общност в употребата на най-характерните граматикализирани предлози в балканските езици // Годишник на Софийския университет. Факултет по славянски филологии 66/1, 1972. С. 179-250.

Асенова 2002 - Асенова П. Балканско езикознание. Велико Търново: Фабер, 2002. БРФР - Калдиева-Захариева, С. Румънско-български фразеологичен речник. София: АИ „Проф. Марин Дринов“, 1997.

CP - Cyrillomethodiana. Старобългарски речник. Available online at: https:// histdict.uni-sofia.bg/oldbgdict, Accessed on 2021-03-01.

МДАБЯ - Малый диалектологический атлас балканских языков. Под редакцией А. Н. Соболева. Серия грамматическая Том I. Категории имени существительного. München: Biblion Verlag, 2005. 